\title{
Invited Address: James Joyce, Alice in Wonderland, the Rolling Stones, and Criminal Careers
}

\author{
Alex R. Piquero
}

Published online: 4 June 2011

(C) Springer Science+Business Media, LLC 2011

\begin{abstract}
The study of criminal careers generally, and patterns of continuity and change in criminal offending in particular, has been a long-standing interest to social scientists across many disciplines. This article provides readers with an overview of this line of research. After an introduction to the criminal career perspective, the article presents several 'facts' that have emerged from criminal career studies. This material segues into a discussion of theories based on criminal careers research as well as a related discussion of the emerging methods and trends in the area. The article closes with some observations about public policy with respect to criminal careers knowledge and identifies some neglected research needs. A key summary conclusion is that the processes associated with continuity and change are not mutually exclusive, but instead are important and complimentary aspects of criminal careers research.
\end{abstract}

Keywords Criminal careers · Continuity · Change · Longitudinal

This paper was presented at the Department of Criminal Justice at Indiana University (May 12, 2011) and was made possible by the generous support of Skip Elliott, an alumnus of the Department of Criminal Justice and the first recipient of its Distinguished Alumni Award.

A. R. Piquero $(\square)$

University of Texas at Dallas, Richardson, TX, USA

e-mail: apiquero@utdallas.edu
What if James Joyce and Alice in Wonderland bumped into one another at a Rolling Stones concert-how would the conversation about criminal careers go? James surely would stress continuity: "I am tomorrow, or some future day, what I establish today. I am today what I established yesterday or some previous day" (James Joyce 1882-1941). Alice, on the other hand, would likely stress change. Consider her interaction with the Caterpillar in Chapter 5: “... at least I know who I was when I got up this morning, but I think I must have been changed several times since then...[the Caterpillar] puffed away without speaking, but at last it unfolded its arms, took the hookah out of its mouth again, and said, 'So you think you're changed, do you? 'I'm afraid I am, sir,' said Alice; 'I can't remember things as I used—and I don't keep the same size for 10 min together!"”

Joyce's observation of a strong past/present relationship is consistent with the criminological evidence linking individual-level continuity in offending from childhood to adolescence to adulthood. [Indeed, continuity is a pesky little fact of human behavior, and the realm of crime is no different.] Decades of research consistently shows that the best predictor of future antisocial behavior is prior antisocial behavior (Nagin and Paternoster 1991, 2000). So strong is the continuity finding that Robins' $(1978$, p. 611) statement that "adult antisocial behavior virtually requires childhood antisocial behavior" occupies a central place in some of criminology's main theories (Gottfredson and Hirschi 1990).

Yet, Alice's observation of change is also consistent with criminological evidence showing that the majority of youthful offenders curtail their criminal activity by the middle to end of adolescence. Robins (1978, p. 611) further shows that most antisocial children do not become antisocial as adults. Sampson and Laub (1993, p. 14, emphasis 
in original) comment poignantly on the fact that change may in fact be the real constancy:

Looking back over the careers of adult criminals exaggerates the prevalence of stability. Looking forward from youth reveals the successes and failures, including adolescent delinquents who go on to be normal functioning adults. This is the paradox noted earlier: adult criminality seems to be always preceded by childhood misconduct, but most conduct-disordered children do not become antisocial or criminal adults (Robins 1978).

In this paper, I seek to accomplish several goals. First, I provide a brief overview of the criminal career perspective, which is then followed by a listing of the facts that have been generated from this work. A discussion of theories based on criminal careers research ensues, which is followed by a brief review of emerging methods and trends in criminal careers research. The essay closes with some observations about public policy with respect to criminal careers knowledge and an identification of some of the uncharted areas in criminal careers research. It will be seen that as applied to antisocial and criminal behavior, the processes associated with continuity and change may, at first glance, be viewed as mutually exclusive. But an important lesson is that continuity and change are actually part and parcel of criminal careers, more complimentarythan contrarian-to one another.

\section{Criminal Careers}

The study of criminal careers focuses on the longitudinal patterning of crime across age, from its origin to its cessation. Such research has had a long history in criminology, dating back at least to the 1800s (Kobner 1893; see review in Piquero et al. 2003). This line of work has produced one of the most replicable yet controversial of all criminological facts: the relationship between age and crime.

Many previous days ago, Quetelet (1831) published Research on the Propensity for Crime at Different Ages. Figure 4 of that book presents what may in fact be the first aggregate representation of the age/crime curve, with its increasing slope to the late teenage years, peaking soon thereafter, and declining precipitously into and throughout adulthood. So strong is that effect that Quetelet (pp. 64-65, emphasis in original) stated: "1. Age is without contradiction the cause which acts with the most energy to develop or moderate the propensity for crime....2. This fatal propensity seems to develop in proportion to the intensity of physical strength and passions in man. It attains its maximum around 25 years, a period where physical development is pretty nearly ended. Intellectual and moral development, which takes place with more slowness, then moderates the propensity for crime which diminishes still more slowly by the weakening of man's physical strength and passions."

From many previous days to today (and likely some future days), the age effect continues to occupy a central place in criminology. Gottfredson and Hirschi (1990, p. 124) conclude that the "age effect is everywhere and at all times the same." Their 'invariance thesis' claim is such that, to them (p. 124), "no current theory of crime can accommodate what [is] perhaps the largest correlate of crime." And the decline in crime with age for these theorists is much like it is for Quetelet: “There is, however, a decline in crime with age. Since this decline cannot be explained by change in the person or by his exposure to anticriminal institutions, we are left with the conclusion that it is due to the inexorable aging of the organism" (p. 141).

Throughout the twentieth century, data were collected in order to study criminal behavior at a more individual-level of analysis, such that researchers could study the relationship between age and crime among persons as they aged into adulthood. The seminal work done here was Wolfgang et al. (1972) Delinquency in a Birth Cohort, which traced the criminal careers of 9,945 boys born in Philadelphia in 1945 and followed to age 18. Several important findings emerged from their study, including the facts that (1) about one-third of the cohort had a police contact by age 18 and (2) a small percentage of the sample $(<6 \%)$ termed 'chronic offenders' was responsible for over half of the cohort's contacts by age 18. Several other longitudinal studies were subsequently carried out to replicate and extend this early study throughout the world using a variety of samples and methods (see Piquero et al. 2003).

A culmination of the results of these studies appeared in a report commissioned by the National Academy of Sciences, Criminal Careers and "Career Criminals" (Blumstetin et al. 1986). Described as a "watershed event" (Osgood 2005), the National Academy of Science's report summarized the key issues involved in criminal careers research, reviewed the available evidence on longitudinal offending patterns, and offered a framework to consider individual criminal careers designed to parcel offending histories through the lens of distinct criminal career parameters to include prevalence, frequency, onset, specialization, escalation, co-offending, seriousness, career length, and desistance. ${ }^{1}$

\footnotetext{
${ }^{1}$ To be sure, not all researchers see value in the criminal career framework. Although there is much to their critique, Gottfredson and Hirschi (1990) take aim at the framework through the lens of the age/ crime relationship. These theorists contend that the shape of the aggregate age/crime relationship is pretty much the same for all offenders, in all times and places, and is largely unaffected by life events that occur after childhood. Thus, because involvement in crime is sufficiently stable over the life course, there is little need to collect and analyze longitudinal data, which is necessary under the criminal career framework.
} 


\section{Criminal Career Facts}

The research initially summarized by Blumstetin et al. (1986), recently updated by Piquero et al. (2003) and DeLisi and Piquero (2011), has generated an important list of well-accepted conclusions about individual criminal careers and the development of offending that been replicated under a variety of conditions. As summarized by Farrington (2003, p. 2), these include:

1. The age of onset of offending is most typically between ages 8 and 14, earlier with self-report data and later with official records, while the age of desistance from offending is most typically between 20 and 29 (though a small subset of offenders continue well into adulthood).

2. The prevalence of offending peaks in the late teenage years-between ages 15 and 19 .

3. An early age of onset predicts a relatively long criminal career duration and the commission of relatively more offenses.

4. There is marked continuity in offending and antisocial behavior from childhood to the teenage years and to adulthood. In other words, there is relative stability of the ordering of people on some measure of antisocial behavior over time, and people who commit relatively many offenses during one age range have a high probability of also committing relatively many offenses during another age range.

5. A small fraction of the population ('chronic offenders') commit a large fraction of all crimes; chronic offenders tend to have an early onset, a high individual offending frequency, and a long criminal career.

6. Offending is more versatile than specialized; violent offenders in particular appear to offend frequently in other kinds of offenses.

7. The types of acts defined as offenses are elements of a larger syndrome of antisocial behavior that includes heavy drinking, reckless driving, promiscuous sex, and so forth.

8. It appears that, as people enter adulthood, they change from group to lone offending. In fact, most offenses up to the late teenage years are committed with others, whereas most offenses from age 20 onwards are committed alone.

9. The reasons given for offending up to the late teenage years are quite variable including excitement/enjoyment, out of boredom, and/or emotional ones, as well as utilitarian ones. From age 20 onwards, utilitarian motives become increasingly dominant.

10. Different types of offenses tend to be first committed at distinctively different ages. This sort of progression is such that shoplifting tends to be committed before burglary, burglary before robbery and so forth. In general, diversification increases up to age 20 , but after age 20, diversification decreases and specialization increases. ${ }^{2}$

Although not directly responsible for spurning the development of criminological theories geared around these conclusions, these findings have served as a strong under-pinning of several prominent theories aimed at studying longitudinal offending patterns.

\section{Theory Informed by Criminal Careers Research}

The articulation of the criminal career framework and related empirical research provided some impetus for

2 Still, there exist some contentious DLC issues that have been illstudied and/or have generated discrepant results, and Farrington documents at least eight such issues: (1) while it is clear that the prevalence of offending peaks in the late teenage years, it is less clear how the individual offending frequency (i.e., the frequency of offending among those who offend) varies with age. Some studies suggest that individual offending frequency accelerates to a peak in the late teenage years and decelerates in the $20 \mathrm{~s}$, whereas others suggest that individual offending frequency changes much less with age. (2) It is not clear whether the seriousness of offending escalates up to a certain age and then de-escalates, or whether it is much more stable with age. (3) While it is clear that an early onset of offending predicts a long career and many offenses, it is far less clear whether an early onset predicts a high individual offending frequency or a high average seriousness of offending. Nor is it clear whether early onset offenders differ in degree or in kind from later onset offenders or how much there are distinctly different behavioral trajectories. (4) Although chronic offenders commit more offenses than others, it is not clear whether their offenses are more serious on average or whether chronic offenders differ in degree or in kind from nonchronic offenders. (5) While it is clear that certain offenses occur on average before other types and that onset sequences can be identified, it is not clear whether these onset sequences are merely ageappropriate behavioral manifestations of some common underlying theoretical construct or if the onset of one type of behavior facilitates or acts as a stepping stone toward the onset of another. In other words, onset sequences could reflect persistent heterogeneity or state dependence. Similarly, little is known about onset sequences in which childhood antisocial behavior might have some kind of influence on later offending. (6) Although there appears to be some research indicating that offenders are more versatile than specialized, these findings have been produced largely by research using official records through age 18 . Very little information has been provided about how specialization/versatility varies with age into adulthood. Even less attention has been paid to the extent to which observations of specialization or versatility vary between official and self-report records. (7) While much attention has been paid to the topic of desistance, little attention has been paid to developing estimates of career length or duration as well as residual career length. Such information bears directly on policy issues regarding appropriate sentence lengths. For example, shorter residual careers would suggest shorter rather than longer sentences. (8) There has been very little research conducted on co-offending generally or on changes in cooffending over the course of a criminal career specifically. 
theorists to consider how their explanations were able to account for the various criminal career dimensions. In this regard, a number of theories were developed that sought to describe and understand the longitudinal patterning of criminal activity over time, and most fall under the rubric of Developmental/Life-Course (DLC) criminology.

Most DLC theories are concerned with the relationship between age/crime and the relationship of prior to future criminal activity. Also common to DLC theory is that they seek to understand the different trajectories of offending over time as well as how various factors and life events (transitions) relate to changes in offending trajectories at different periods of the life course. In this regard, DLC focuses on the temporal, within-individual changes in offending over time (Le Blanc and Loeber 1998, p. 117) and thus adopts a non-static, developmental orientation that permits differences between offenders and within offenders across age. In sum, then, DLC theories are strongly attuned to Robins' observation that although antisocial behavior in children is one of the best predictors of antisocial behavior in adults, not all antisocial children become antisocial adults. This section presents two theories that attempt to understand longitudinal offending patterns through a DLC lens, but do so in very different ways.

Moffitt's (1993) developmental taxonomy starts with the aggregate age/crime curve, but then proposes that it hides two distinct groups of offenders. The first group, "lifecourse-persistent", is reminiscent of Wolfgang et al.'s 'chronic offenders', and is anticipated to be involved in a wide swath of antisocial and criminal acts over the life course. Like Wolfgang et al., this group of offenders is presumed to be a very small fraction of the offending population $(<10 \%)$. The etiology of life-course-persistent offending lies in the interaction between poor neuropsychological functioning and deficient home and socio-economic environments. Beginning early in life, this interactive combination is not met with positive prospects for change, and as a consequence begins to solidify and permeate many life domains. Offenders on the life-course-persistent path continue offending throughout most of their lives and are hypothesized to be involved in a myriad of criminal acts including interpersonal violence. Also, Moffitt expects such individuals to encounter other problems in education, employment, health, and inter-personal relationships.

The second group, "adolescence-limited", represent the largest number of offenders and account for a good portion of the offending observed around the peek offending ages, but also limit their offending to the adolescent period. Offending among adolescence-limiteds is due to location in the maturity gap (i.e., adolescents are physically old enough to look like adults, but socially not allowed to act like adults) and the aid, comfort, and encouragement of the peer social context. Because of their yearning to become adults, Moffitt expects these offenders to restrict their antisocial acts to mainly status and property-oriented offenses that resemble adult social status such as theft, smoking, vandalism, and drug use. Because adolescencelimiteds do not have the injurious childhoods that inflict life-course-persisters, their prosocial skills and attitudes allow them to recover from their delinquent flirtation and desist by late adolescence/early adulthood.

Thus, in understanding the linkage between prior/future offending, Moffitt attributes saliency to a state dependent argument among adolescence-limiteds, in large part because they are influenced much more by situational factors. Thus, criminal involvement is likely to causally affect future criminal involvement among adolescencelimiteds because offending further alienates conventional others. For life-course-persisters however, continued offending is likely a consequence of persistent heterogeneity (and to a lesser extent state dependence processes). ${ }^{3}$

Although space precludes a detailed review of the research testing Moffitt's theory, an accumulated body of findings tends to support some of her critical hypotheses (see Moffitt 2006; Piquero and Moffitt 2005). Still, some studies have generated useful alterations to the theory (Nagin et al. 1995) which Moffitt has considered for further theoretical development, while others have presented some important challenges (Laub and Sampson 2003).

As can be seen, Moffitt's theory permits both static and dynamic effects for specific sub-groups of offenders. A competing DLC theory that emerged after the criminal career report is Sampson and Laub's (1993) age-graded informal social control theory that permits both static and dynamic effects on criminal activity over the life-course, but without the specification of distinct offender trajectories.

Sampson and Laub's (1993) theory incorporates both persistent individual differences and state dependent life events in its explanation of criminal offending. Their theory begins with three critical notions. First, delinquency in the first decade and a half can be understood, in part, by the structural context which is mediated by informal family and school social controls. Second, they incorporate continuity directly into their theory as a way to link antisocial behavior from childhood into adulthood, and in this regard are open to the importance of persistent heterogeneity influencing criminal offending. Third, and most importantly, they explain many of the changes that occur in early adulthood with respect to (lower) crime as a function of the variation in the quality of informal social bonds to (mainly) family and employment in adulthood, even after persistent

\footnotetext{
3 To be sure, Moffitt (1993) does allow for some adolescence-limited to encounter snares that keep them on track for continued crime, and for the possibility that the life-course-persistent pathway may not be entirely static (or driven by persistent heterogeneity).
} 
individual differences are considered. These theorists argue that, independent of persistent individual differences, informal social controls exert a causal, state dependent effect on offending. Thus, their theory incorporates both continuity and change in crime throughout the life course, but does so without the articulation of distinct offender groups.

Sampson and Laub have continued elaborating their theory and two specific ones are noted here. The first incorporates a developmental conceptualization of labeling theory, which invokes a state dependence argument of prior delinquency facilitating adult crime through a process of "cumulative disadvantage". According to Sampson and Laub (1997, p. 144), involvement in delinquency has a "systematic attenuating effect on the social and institutional bonds linking adults to society (e.g., labor force attachment, marital cohesion)." Thus, delinquency is indirectly related to future offending because it leads to school failure, incarceration, and weak bonds to the labor market, all of which likely lead to further adult crime. A second elaboration emerges from their recent qualitative narratives with a subset of their original sample, followed into middle/late adulthood. Specifically, Laub and Sampson (2003) identified personal human agency in the offending careers of some persistent offenders in which some men chose to continue involvement in crime. Their (p. 281) notion of "situated choice" is advanced as a concept meant to illuminate how individuals are influenced by the interaction of structure and choice. Thus, while their theory is friendly to the importance of continuity and especially change due to life events, "action is necessary to complete the turning" (Abbott 1997, 102).

Several studies have examined Sampson and Laub's stability/change thesis and report results consistent with their view that both persistent individual differences (stability) and local life circumstances (change) are important for understanding offending over the life-course (Blokland and Nieuwbeerta 2005; Horney et al. 1995; Laub and Sampson 2003; Paternoster et al. 1997; Piquero et al. 2002a). It is also important to note that studies have also shown that the type and quality of life circumstances and not just the mere presence of it, is important for aiding the desistance process (Laub et al. 1998).

In sum, both Moffitt and Sampson and Laub agree on the importance of studying within-individual change in both criminal activity and the factors associated with criminal activity over the life-course, but they have important differences. Sampson and Laub provide a general, non-typological, dynamic theory of offending that incorporates continuity and especially change in a general framework applicable across all offenders, while Moffitt articulates a non-general, typological, static/dynamic theory of offending. In this regard, the former is less complex than the latter because of the lack of distinct offender trajectories, and also because the factors that predict offending in the former do not differ across offenders while they most certainly do in the latter.

\section{Methodological Advances and Their Relation to Criminal Careers Research}

As data sources and theory have expanded in breadth and scope, the methods used to study criminal careers have also made great strides and have, in several instances, yielded important new insight that had not been previously determinable with older methodological techniques. Here, I review two strands of methodological approaches, qualitative and quantitative.

As noted earlier, the historical interest in longitudinal patterns of offending can be traced back to Quetelet. However, several key studies in criminology have generated some of the most important insights into offenders' lives, beginning largely with Shaw's (1930) The Jack Roller. This classic work detailed the life story (into adolescence) of Stanley, an institutionalized delinquent, who provided Shaw with a detailed set of narratives regarding his behavior and social background. This study served as a major piece of scholarship that brought to light some of the decision-making processes used by Stanley as well as how he interpreted some of the things that happened to him throughout the course of his life. Other qualitative work in the area of offender decision-making (Shover 1996; Wright and Decker 1994, 1997) has also provided important insight into how offenders make offending decisions, which targets they approach, how they rationalize their behavior, and how and why they decide to curtail their offending. Laub and Sampson's (2003) recent interviews with some of the Glueck males in their 60s provided new insight into how and why life events mattered in some cases for desistance but failed to do so in other cases. Further, their interviews revealed some of the human agency involved in offenders continuing to choose involvement in offending even after being punished for previous acts.

Aside from the insight gleaned from the qualitative research, researchers have developed sophisticated methodological techniques for uncovering unique patterns of offending over the life course and for studying how continuity and change play out over time with respect to offending. Although these methods vary in how they approach the problem, they all do share common ground as 
a result of their interest in studying patterns of offending. Here, I provide a review of one specific method based on identifying distinct offender trajectories, the semiparametric mixed poisson model (SPM).

Recognizing that there may be variation within the population of offenders, Nagin and Land (1993) developed a methodology that could examine: whether there are distinct clusters of offenders, whether they differ in their offending from one another in important ways, whether they are distinguishable from one another across key risk/ protective factors, and whether individuals following different trajectories also respond differently to an intervention. (Note: A more detailed overview of the methodology may be found in Nagin (2005) and Nagin and Piquero (2010)).

In brief, this method assumes (a small number of) distinct life course patterns/groups that characterize offender heterogeneity. Each individual in a particular set of data has some non-zero probability of being assigned to each discrete group that is identified and then is assigned to the group to which s/he has the highest probability of belonging. The methodology also takes into consideration periods of non-offending and also makes use of different estimators for charting distinct developmental trajectories that do not vary regularly throughout the population, much as is true of antisocial behavior.

There have been well over one-hundred applications of this methodology to a variety of longitudinal offending data (Piquero 2008), with findings showing distinct heterogeneity within the offending population. Some trajectories are observed to start early and continue steadily into early adulthood, while other trajectories begin to appear in adolescence, peaking soon thereafter, and then declining into adulthood-findings which provide visual evidence in favor of some theories (such as Moffitt's) that are indiscernible with other methodologies. At the same time, many of these same investigations have also found other offender trajectories that do not 'fit' Moffitt's theory and also shows that in some cases, the most chronic trajectories of all desist much sooner than may have been anticipated. These findings have led Moffitt (2006) in particular, to revisit some of her groupbased expectations. Further, it is also the case that in many instances, groups are distinguishable on critical variables as extant theory would predict, and in other cases there has been some evidence showing that life events can alter previous trajectories either upward or downward depending on the life event and how individuals respond toward it.

In short, qualitative and quantitative methods applied to longitudinal offending data have provided important descriptive and predictive information about the nature of offending and in some cases recently developed techniques and applications of the methodologies have generated important new theoretical insight, modification, and questions for subsequent analysis. In the next section, I review some of the new trends in criminal careers research, some of which has been spurred by these developments and findings.

\section{New Trends in Criminal Careers Research}

Research on criminal careers has provided some useful descriptions of longitudinal offending patterns and has also led to the identification of some important differences across offenders as well as how different risk/protective factors and life events relate to various criminal career dimensions, especially with respect to persistence/desistance from criminal offending. At the same time, a different strand of research has started to examine criminal offending and criminal careers not as outcomes but instead as predictors of how involvement in offending leads to adverse outcomes in other life domains.

These investigations have linked criminal offending in general, and frequent offending (and offenders) in particular to a wide range of negative outcomes to include accidents, injuries drug/alcohol addiction, overall health, and death (cf. Nieuwbeerta and Piquero 2008). For example, Farrington's (1995) analysis of males participating in the Cambridge Study in Delinquent Development revealed that offending was predictive of a wide array of poor health outcomes. Follow-up studies using the Cambridge data presented further evidence of these relationships. Piquero et al. (2010b) examined how distinct offending trajectories identified by age 40 predicted a measure of life success (to include mental health, substance use, and employment among other things) and found that although most of the men were leading successful lives, those individuals who were considered high-rate chronic offenders were evidencing the highest life failure at age 48. A more detailed report by Piquero et al. (2011a) further uncovered that the offender trajectories differed from one another on two specific health outcomes, being registered disabled and hospitalization, with high-rate chronic offenders having the highest risk for both outcomes independent of childhood individual/environmental risk factors. Finally, in an analysis of data from the Dunedin Health and Human Development Study, a birth cohort of persons born in Dunedin, New Zealand in the early 1970s and followed into adulthood, Odgers et al. (2007) linked developmental trajectories of conduct problems between ages 7-26 years to physical and mental health problems at age 32 . These authors found that individuals classified into the lifecourse-persistent trajectory experienced the worst health outcomes.

Of course, offending and its negative outcomes entail many costs not only to victims and offenders, but also to 
the overall populace. As a result, some investigators have turned to an analysis of the costs-of-crime for summarizing the economic toll that offenders-especially frequent and serious offenders-exert on society. A seminal study by Cohen (1998) derived an estimate of the external costs imposed by a typical career criminal to be $\$ 1.3$ to $\$ 1.5$ million in 1997, but that the worst offenders were estimated to impose costs as high as \$36 million. When Cohen combined estimates from offending, dropping out of high school, and abusing heavy drugs, he reported that the monetary value of saving a high risk youth was between $\$ 1.7$ and $\$ 2.3$ million. His study was recently updated by Cohen and Piquero (2009), who examined the offending behavior of all 27,186 individuals from the 1958 Philadelphia Birth Cohort study. These authors used new estimates of the costs of individual crimes that were more comprehensive and that increased the monetary cost per crime. These authors reported an estimate of the present value of saving a 14-year old high risk juvenile from a life of crime to range from $\$ 2.6$ to $\$ 5.3$ million, and that saving a high risk youth at birth would save society between $\$ 2.6$ and $\$ 4.4$ million. Their work was furthered by adopting the trajectory methodology and considering how the costs-ofcrime varied across offender trajectories. In that study, Cohen et al. (2010a) linked offender trajectories estimated from the 1958 Philadelphia Birth Cohort to the monetary costs associated with the criminal offending and found that chronic offenders who commit crimes frequently when young turn to more serious crimes as adults and impose far greater costs than low-frequency chronic offenders and those whose offending peaks during adolescence. In finding that the most high-rate chronic group accounted for a disproportionate dollar amount, they noted that preventing individuals from becoming high-rate chronic offenders would yield significant cost savings of upwards of $\$ 200$ million dollars. Cohen et al. (2010b) further estimated that the costs-of-offending in the Philadelphia data were differentially born out by race/sex, indicating that males and African-Americans incurred the highest offending costs. Finally, in one of the only studies to be conducted internationally on the individual-level costs-of-crime issue, Piquero et al. (2011b) merged the Cambridge male offending trajectory groups discussed earlier with individual-level offending and individual costs-of-crime data and found that the costs of high rate chronic offending was nearly two and a half to ten times greater than the costs of high adolescence peaked offending, very low rate chronic offending, and low adolescence peaked offending, respectively, and that a high rate chronic offender on average would exert a crime penalty of $£ 1,494(\$ 2,381)$ per U.K. citizen. In sum, these and related (DeLisi and Gatling 2003; Welsh et al. 2008) studies indicate that offending over the life-course incurs a considerable amount of economic and social costs and that these costs are differentially distributed across offending trajectories.

\section{Policy Issues}

The research documenting that a small number of individuals were responsible for a large portion of crime morphed into the policy discussion and subsequent implementation of selective incapacitation, which involved the incapacitation of the most high-rate offenders. The promise under selective incapacitation was that much of the crime problem could be eliminated if high-rate offenders were incapacitated early enough to prevent their involvement in frequent and serious offending. The problem, of course, under a selective incapacitation strategy lies in correctly identifying which offender is destined to become a high-rate offender early enough in the life course before they become high-rate in order to prevent such offending. The prediction of such individuals however, proved very difficult as several studies uncovered a relatively high false positive rate, such that individuals predicted to be high-rate were not, and also a false negative problem-predicting that some individuals would not become high-rate offenders when in fact they did end up becoming high-rate offenders. An additional limitation concerned the factors that were believed to be able to prospectively distinguish which individuals would become high-rate offenders, and this line of work generated disappointments as studies also failed to demonstrate a strong cadre of verifiable and replicable risk factors that were able to prospectively and accurately predict high-rate offenders (Auerhahn 1999).

The interest in and application of selective incapacitation waned as a result of identification problems and as public policy turned more punitive with the development and application of long-term prison sentences and mandatory minimums. These decisions, unfortunately, produced several associated problems that are being borne out today as correctional budgets have become strained with municipalities and states having to bear the high cost of incarcerating many offenders and for very long periods of time. These decisions about long-term sentences have the potentially undesirable consequence in that they incarcerate offenders long past their peak involvement in crime.

One avenue of criminal careers research that had emerged in the 1980s but that did not gain much traction concerned the study of residual career length (Blumstein et al. 1982), which attempted to derive an estimate of how long criminal careers not only were in duration but more important how long they were anticipated to last. Knowledge gleaned from producing residual career length estimates is important not only because it may be used as a 
consideration in the incarceration policy discussions but also because such estimates can be derived in longitudinal data sources by a particular point in the life course and then follow-up data can be collected thereafter in an effort to determine the accuracy of such predictions and then help to identify places where the estimates may be strengthened and solidified (Blumstein and Piquero 2007; Piquero and Blumstein 2007; Piquero et al. 2004). Some recent work on residual career length offers some promise in this regard, not only with respect to developing estimates of residual career length but also the extent to which various early childhood risk factors predict residual career length in adulthood (Kazemian and Farrington 2006).

One interesting extension of this overall program of research on criminal career length deals with research on the issue of redemption. Here, the focus is not on finding a specific life event or cause that all-of-the-sudden makes an individual stop offending, but instead focuses on the relationship between time and offending frequency by examining the individual offending data in order to derive estimates of how likely an individual is to offend at a specific point in time given their previous level of involvement and then develops estimates of an individual's predicted probability of offending to assess the point in time in which an individual's probability of offending becomes virtually indistinguishable from a non-offender. Several recent examples of this line of work have generated very useful preliminary estimates and substantive implications for public policy (Kurlychek et al. 2007).

As an illustration of the policy relevance of this issue as applied to employment, Blumstein and Nakamura (2009) asked whether it was possible to determine empirically when it was no longer necessary for an employer to be concerned about a criminal offense in a prospective employee's past? In other words, can knowledge about criminal careers (length, frequency, rate, timing) be used in developing some sense of what point in time in an individual's criminal career it would be safe to overlook one's criminal record and safely assume that the risk of offending is virtually zero. These authors, then, conducted a study to "actuarially" estimate a point in time when an individual with a criminal record is at no greater risk of committing another crime than other individuals of the same age.

In order to do so, Blumstein and Nakamura created a model for assessing the issue of redemption by obtaining criminal history records of 88,000 individuals who were arrested for the first time in New York in 1980. First, they determined whether the individuals had committed any other crime(s) during the ensuing 25 years or if they had stayed clean. This data was subsequently compared against two populations: individuals in the general population who were the same age and individuals of the same age who had never been arrested. Findings showed that the younger an offender was when he committed robbery, the longer he had to stay clean to reach the same arrest rate as people his same age in the general population. Similar results were obtained for the individuals whose first offenses were for burglary and aggravated assault. In sum, the probability of new arrests for offenders declined over the years and eventually became as low as the general population as the number of years since first arrest increased.

Aside from the policy-related issues of incapacitation and redemption, another set of policy considerations deals with prevention and intervention strategies that recognize the important foreshadowing of early antisocial behavior and seek to apply programming early in the life course in an attempt to delay the start of - and intervening early incriminal careers. Two in particular are family training programs (in the context of nurse home visitations) and self-control modification programs.

Broadly speaking, these programs are based on the notion that quality of parent-child relations will facilitate learning of control over impulsive, oppositional, and aggressive behavior, thus reducing disruptive behavior and its long-term negative impact on social integration. These programs attempt to change the social contingencies in the family context and provide guidance to parents on raising their children or general parent education.

There are two main types of early family/parent training programs. The first is nurse home visitation, in which nurses or related health service workers visit pregnant mothers and work with them to improve their prenatal health status, reduce birth complications, and provide guidance and support in caring for the infant and improving the quality of their own lives. The second combines parent training, daycare, and preschool for parents with preschool children. These in particular seek to advance cognitive and social development of the children, as well as the parenting skills of their caregivers, so that participants will be better prepared and more successful when they enter regular school.

Largely based on the results of a very important experiment that developed and evaluated a nurse home visitation program in upstate New York and uncovered a set of very positive outcomes among the youth subject to the intervention as they entered middle/late adolescence (Olds et al. 1998), there has been a growing application of these programs around the world. In an effort to develop an overall sense of the results of these various efforts, Piquero et al. (2009) performed a meta-analysis of 55 studies that focused on the early family/parent training programs implemented in early childhood (through age 5) for 
reducing child behavior problems (antisocial behavior and delinquency). All of the studies eligible for their analysis had to have strong methodological rigor such that they were randomized, controlled experimental studies including pre-post evaluations of family programs. These authors also undertook a series of alternative analyses where they investigated the settings and conditions that made the program most effective. Their findings indicated that early family/parent training was an effective intervention for reducing antisocial problems and delinquency as well as in reducing delinquency and crime in later adolescence and adulthood, and that the produced effect size was in the small-to-moderate range. The findings were also robust across various weighting procedures, and across context, time period, sample size, outcome source, and based on both published and unpublished data. When these results are combined with research documenting that citizens believe in early prevention (Piquero et al. 2010a) and are willing to pay for these programs (Nagin et al. 2006), it appears that such programs targeting family/parenting practices very early in the life course is likely to pay dividends across a variety of life domains, to include less antisocial behavior.

Aside from early family/parent training programs, another set of efforts focus on self-control modification. Recognizing the strong linkage that self-control has to antisocial behavior throughout the life course and across various life domains, these programs seek to improve self-control in children and lessen involvement in delinquency and related problem behaviors. A large array of such programs exists, but very few have been rigorously developed and evaluated. Piquero et al. (2010c) sought to examine how these programs, overall, influenced selfcontrol and, in turn, problem behaviors, by conducting a meta-analysis of studies that had a randomized controlled evaluation design that provided post-test measures of selfcontrol and/or delinquency and problem behaviors among experimental and control subjects up to age 10. Thirtyfour studies met their stringent criteria and the overall results indicated that self-control improvement programs were an effective intervention for improving self-control and reducing delinquency and problem behaviors, and that the effect of these programs was rather robust across various weighting procedures, and across context, outcome source, and based on both published and unpublished data. Importantly, then, the results show that selfcontrol is malleable and that efforts designed to improve self-control in children can be effective and can evince delinquency-lessening benefits.

In sum, positive findings exist for (at least) these two prevention strategies that seek to improve people's lives. So as a general public policy to be applied at the area-level (as opposed to identifying and potentially mis-identifying specific individuals) it is likely that these efforts should be applied broadly and scaled up. ${ }^{4}$

\section{The More Things Change...the More They Stay the Same? A Glimpse into the Criminal Career Crystal Ball}

If I were to think ahead 10 years to what the 10th Elliott Lecturer would say about criminal careers and DLC, what would s/he say? Unfortunately, I, even drawing from the prowess of either James, Alice, or the Glimmer Twins do not hold such prognosticatory power. Nevertheless, I do hope that there is sufficient interest in studying some of the following issues, which when taken together and placed in the context of extant criminal careers research, is likely to help further theoretical and empirical development that will help inform public policy discussion and ultimately and hopefully public policy decision-making.

First, there is the more general over-arching point that basic descriptive research is desperately needed that investigates the continuity of offending from adolescence to adulthood because this is the period when many policy officials will make decisions regarding the incarceration of offenders-some of whom will curtail their offending naturally and some of whom will persist into adulthood (Piquero et al. 2011c). As few studies have dealt with specific criminal career dimensions linking the transition between the juvenile and adult years, a period of the life course when many criminal careers end and a small select few continue, this is an important time period to study offending patterns (Piquero et al. 2011a).

Second, the voluminous literature on descriptive patterns and features of criminal careers has certainly generated an important array of basic findings regarding longitudinal offending patterns. This in and of itself is critically important because the field needs basic knowledge about offenders and their offending and description is critical to any scientific and policy endeavor. At the same time, these findings have also helped uncover several important and relatively uncharted areas of investigation that need attention. Three criminal careers dimensions are relevant here and include two that are strongly linked, intermittency and desistance, and a third dealing with co-offending.

Loosely defined, intermittency refers to the time gaps between offending episodes. Basic information is needed

\footnotetext{
${ }^{4}$ Of course, targeting individuals who most need specific treatment is ideal, but in the case of nurse home visits and self-control improvement programs, it seems that the negative outcomes are virtually non-existent and the positive outcomes better and very costfriendly especially when considered over the long-term and throughout all life domains.
} 
on what these time gaps look like, how they may vary at different points throughout the life course, and what factors help to shorten and extend them. Clearly, the theoretical questions are of interest here, as researchers have documented how short-term changes in life events relate to short-term changes in criminal offending, but the surface has been scratched with only a pencil. Relatedly, the issue of desistance, or the termination of a criminal career, remains important for theory and policy. However, there have only been a few detailed investigations into the patterning and correlates of desistance (Laub et al. 1998; Laub and Sampson 2003; Bushway et al. 2003), largely because of the limitations of datasets (i.e., they have not followed individuals into middle/late adulthood) and the definitional and operationalization concerns surrounding when desistance occurs, i.e., is it an end point or a process (e.g., Bushway et al. 2001). Still, given the intimate linkage between desistance and redemption, this offers an important opportunity for researchers.

On the issue of co-offending, there is a lack of individual-level longitudinal data needed to study offending and co-offending patterns within persons over time (McGloin and Piquero 2009; Goldweber et al. 2011), and that which does exist has tended to focus solely on the juvenile period only, with very few studies containing individual and co-offending data throughout the life course. The minimal research on co-offending patterns in criminal careers shows that it exhibits a strikingly similar profile to the aggregate age-crime curve (Piquero et al. 2007; van Mastrigt and Farrington 2009), that there are distinct trajectories of co-offending over the course of the juvenile criminal career and that juvenile delinquents generally tend not to "re-use" co-offenders, though frequent offenders show a greater propensity to do so (McGloin et al. 2008), that higher levels of co-offender network redundancy (more dense networks) are related to higher levels of specialized offending in group crimes, but no such relationship exists with overall (i.e., solo and group) offending diversity (McGloin and Piquero 2009), and that the presence of more co-offenders (i.e., larger groups) will be related to an increased likelihood of violent crime (McGloin and Piquero 2010). However, these studies emerge from two select data sources (the Cambridge data of South London males and a sample of juvenile offenders followed to age 17); thus, there is an important need to examine cooffending patterns in other data sources, across distinct offense types, and throughout the entire life-course. Also pertinent here is the issue of recruitment and selection of individuals into and out of co-offending networks.

Third, largely due to data issues that have limited longitudinal data sources to include mainly male, mainly white, and mainly US-based samples and offenders, and mainly individual-level behavior to the neglect of social contextual markers, there has not been much investigation on the patterning of criminal careers across demographic groups (Brame et al. 2010). For example, very limited information exists on race and sex differences in criminal careers in general, and with respect to how criminal career dimensions vary across race and sex and the extent to which the correlates of offending vary across race and sex in particular. Basic but critical questions are in need of attention such as: whether males and females evince similar offending trajectories in terms of shape, size, and level; whether male and female careers are influenced by a similar set of factors at similar periods of the life course; whether African-American, White, and Hispanic criminal careers look the same and whether the correlates of their offending are more similar than different; and whether there exists variation at the neighborhood level with respect to criminal career formation and trajectory.

There has been some limited work on these issues. D'Unger et al. (1998), Piquero and Moffitt (2005), Jennings et al. (2010), and Fitzgerald et al. (2011) examined sex differences in offending trajectories, while Maldonado-Molina et al. (2009) examined longitudinal offending patterns and risk factors among two samples of Puerto Rican youth, one reared in the Bronx, New York and the other in San Juan, Puerto Rico. Authors have also examined how different risk/ protective factors distinguish across trajectories (Loeber et al. 2008). Piquero et al. (2002b) examined how life events related to persistence/desistance across white and non-white California Youth Authority parolees followed for seven consecutive years, and Ludwig et al. (2001) used data from the Moving to Opportunity data to examine how changes in neighborhood residence related to changes in delinquent activity. Yet, these demographically-stratified investigations pale in comparison to the larger stock of criminal career research focusing on whites, males, and US-based samples.

Fourth, picking up on some of the new and emerging trends in criminal careers research, there awaits an important and very much open area of investigation with respect to the later life outcomes of criminal careers. In particular, the field has limited knowledge about the effects of criminal offending, especially frequent and long-term offending on later-life health, employment, and relationship outcomes. As a result of the link between delinquency and other social problems, measures that succeed in reducing crime will probably have benefits that go far beyond offending. Early prevention that reduces delinquency will probably also reduce drinking, drunk driving, drug use, sexual promiscuity and family violence, and perhaps also school failure, unemployment and marital disharmony. Given the costs of crime that permeate many life domains and the financial toll it exerts on society and the public, documentation and understanding of the offending/life-outcome relationship would be useful. 
Fifth, there will likely be at least three new forays that will mark criminal careers understanding as it relates to furthering and fleshing out criminological and DLC theory. Specifically, these include: decision making styles across offenders (weighing risks rewards ambiguity, etc.), the influence of biosocial and genetic research, and a focus on the interaction of a person and his environment to include the feedback effects of such interactions. Below, I provide a brief note on each of these.

With respect to decision-making styles, criminologists have long been interested in understanding how offenders arrive at the decisions they do with respect to offending, as they consider the costs and benefits of the act. Recent developments in rational choice and deterrence theory have identified important new topics for inquiry on decisionmaking to include paying close attention to individual differences (Piquero et al. 2011c) and to consider notions of ambiguity (Loughran et al. 2011) with respect to risk/ reward calculations. All of this knowledge needs to be next considered in the context of how distinct offender trajectories tabulate and employ such information and then ultimately decide to offend or not. Key here is the notion that perhaps the most high-rate and chronic of offenders do not weight risks and rewards as do most other offenders, or perhaps that they tend to focus on rewards and do not even consider risks (Piquero and Moffitt 2005).

A second area of promising theoretical inquiry and application as it relates to criminal careers concerns the strongly emerging research (at least within criminology) on biosocial and genetic influences. Largely studied in other disciplines, it has only been over the past 20 years or so that this area of work has not only gained in popularity and credibility, but also with respect to the scientific discoveries it has produced (cf. Caspi et al. 2002). And while extant DLC theories in criminology remain friendly to this theoretical tradition (Moffitt 1993), data limitations have precluded a concerted program of research, but this is slowly changing. Important studies have been carried out with respect to how biosocial factors and genetics relate to antisocial behavior and there is little doubt that it will become a very dominant part of the theoretical landscape throughout the next dozen years (Barnes and Beaver 2011; Barnes et al. 2011).

A third area of theoretical promise deals with putting on a different set of glasses to study individuals in context. Making use of the emergence perspective, McGee and Piquero (2011) have called for researchers to study individuals in situational context by focusing on how the various crime-engendering ingredients come together to produce criminal events. In so doing, these authors use the theme of 'person and context' to understand aspects of criminal career dimensions and consider how persistent heterogeneity and state dependence processes can be conceived within the emergence perspective in order to help understand longitudinal patterns of offending and, in turn, develop and/or expand developmental/life-course theories.

In sum, the development, modification, and extension of criminological and DLC theory and application of research in these areas is likely to cast important light on the onset, persistence, and desistance in offending careers. Moreover, they are also likely to provide clues into how interactions may produce differential results depending on an individual's age and social position in life.

Sixth, there is always a need to continue improving methodological techniques so as to gain further and potentially novel insight into criminal careers. Of course, advances in quantitative methods have been very important over the past 20 years, especially with respect to longitudinal analytic methods, and applications of these methods to longitudinal data has generated many important insights. At the same time, qualitative approaches have been increasingly applied to study offender decision-making with respect to criminal offending and these efforts have generated important and novel insight that has not been as easily accessible via quantitative methods (Giordano et al. 2002). For example, Maruna's (2001) and Laub and Sampson's (2003) detailed narratives with offenders has led to important insights into the desistance process and the influence of personal agency in decision-making. Continued application and extension of these methods and in particular their integration is likely to continue providing researchers with new insights and directions for subsequent inquiry. Moreover, further analysis of the relationship between changes in life events and changes in offending is needed not only with respect to sorting out cause/effect issues, but also to expand the range of life events and contexts that offenders encounter. Here, it would also be good to study how different types of antisocial behaviors co-integrate or change at different periods of the life-course (Brame et al. 2001; Monahan and Piquero 2009; Petras et al. 2010; Sullivan and Piquero 2010, 2011). Further collection of detailed life narratives would be important, especially among different types of offenders to include females and members of other races/ethnicities. It may be that patterns of crime and life events vary across these groups in ways that are currently undetectable in quantitative analysis of longitudinal data sets.

Along the same lines, there remains a need for caution about the limitations of these methods and to consider improvements in data collection and retention of hard-totrack subjects. For example, many longitudinal data sets do not have offending information from both official and selfreport sources, thus critical questions remain about the concordance of these measures of offending across the various criminal career dimensions (Blumstein et al. 2010; 
Thornberry and Krohn 2003; Lynam et al. 2004). Additionally, because serious and violent offending is not common in general population surveys, efforts to collect data on serious offenders and track them for long periods of time will be especially relevant, as they are the sample for whom issues related to persistence/desistance is most critical (Mulvey et al. 2004; Laub and Sampson 2001). Another important issue concerns street time, or the amount of time offenders are free and able to offend. Research by Piquero et al. (2001) showed important consequences for not controlling for street time when estimating longitudinal offending trajectories-namely, that the shape and level of the trajectories and the persons in the various trajectories differed depending on whether individual offending behavior was adjusted for street time.

Seventh, research on criminal careers certainly invites policy discussions. In this regard, there is an obvious reminder here that policy proscriptions must be carried out using evidence-based research that is built on strong interand multi-disciplinary theory and that takes great care to document risk and protective factors. It is also critical that research findings stand on a body of replicable evidence, and that such factors are as modifiable as possible-two prime candidates here include parental socialization and individual self-control). Another set of policy decisions deals with how the system reacts to and subsequently punishes offenders and their offending. There has been a historical trend toward incarceration and the costs of those decisions are now being realized-so much so that even liberals and conservatives agree on the need to lessen incarceration but for different reasons! Aside from the monetary concerns associated with expanded imprisonment, there is a pressing need to study the effect of imprisonment at the individual-level. Unfortunately, there are too few examples of methodologically rigorous studies examining this individual-level effect, and whether sanctions deter, exacerbate, or have no effect on crime (Bhati and Piquero 2008; Nagin et al. 2009). Combining these two policy issues further strengthens the need for cost-benefit analysis of the societal and human costs of offending as well as the system's reactions to it (Cohen et al. 2010c).

Lastly, it would be fruitful to study the things that we do not study enough; that is, the off-diagonals. These are the individuals who are predicted to be antisocial but end up conforming as well as the individuals who are predicted to be conforming but end up antisocial. Continuity and discontinuity are both important in studying offending but so too are these negative cases. In my mind, interesting questions lie in cases that do not always turn out the way they should turn out (cf. Piquero et al. 2011c).

To close, then, let's return to James and Alice, with a modification or two. There is some continuity to growing older. As Jules Feiffer observed: “At sixteen I was stupid, confused and indecisive. At twenty-five I was wise, self-confident, prepossessing and assertive. At forty-five I am stupid, confused, insecure and indecisive. Who would have supposed that maturity is only a short break in adolescence?" But there is also some change in growing older. As L.S. McCandless pointed out: "The best thing about getting old is that all those things you couldn't have when you were young you no longer want." I wonder if Mick Jagger and Keith Richards would agree.

\section{References}

Abbott, A. (1997). On the concept of turning point. Comparative Social Research, 16, 85-105.

Auerhahn, K. (1999). Selective incapacitation and the problem of prediction. Criminology, 37, 703-733.

Barnes, J. C., \& Beaver, K. M. (2011). Genetic influences and criminal careers. In R. J.R. Levesque (Ed.), Encyclopedia of adolescence. New York: Springer (doi:1031007/978-1-4419-1695-2).

Barnes, J. C., Beaver, K. M., \& Boutwell, B. B. (2011). Examining the genetic underpinnings to Moffitt's developmental taxonomy: A behavioral genetic analysis. Criminology (forthcoming).

Bhati, A. S., \& Piquero, A. R. (2008). Estimating the impact of incarceration on subsequent offending trajectories: Deterrent, criminogenic, or null effect? Journal of Criminal Law \& Criminology, 98, 207-253.

Blokland, A. A., \& Nieuwbeerta, P. (2005). The effects of life circumstances on longitudinal trajectories of offending. Criminology, 43, 1203-1240.

Blumstein, A., Cohen, J., \& Hsieh, P. (1982). The duration of adult criminal careers. Pittsburgh, Penn: School of Urban and Public Affairs, Carnegie-Mellon University (final report submitted to National Institute of Justice, August 1982).

Blumstein, A., Cohen, J., Piquero, A. R., \& Visher, C. A. (2010). Linking the crime and arrest processes to measure variations in individual arrest risk per crime (Q). Journal of Quantitative Criminology, 26, 533-548.

Blumstein, A., \& Nakamura, K. (2009). Redemption in the presence of widespread criminal background checks. Criminology, 47, 327-359.

Blumstein, A., \& Piquero, A. R. (2007). Criminal careers research and rational sentencing policy. Criminology \& Public Policy, 6, 679-688.

Blumstetin, A., Cohen, J., Roth, J. A., \& Visher, C. A. (Eds.). (1986). Criminal careers and "career criminals". Washington, D.C.: National Academy Press.

Brame, R., Mazerolle, P., \& Piquero, A. R. (2010). Criminal career progression in early adulthood in a sample of serious offenders in Australia. Journal of Criminal Justice, 38, 340-348.

Brame, R., Mulvey, E. P., \& Piquero, A. (2001). On the development of different kinds of criminal activity. Sociological Methods and Research, 29, 319-341.

Bushway, S., Piquero, A., Broidy, L., Cauffman, E., \& Mazerolle, P. (2001). An empirical framework for studying desistance as a process. Criminology, 39, 491-516.

Bushway, S., Thornberry, T. P., \& Krohn, M. D. (2003). Desistance as a developmental process: A comparison of static and dynamic approaches. Journal of Quantitative Criminology, 19, 129-153.

Caspi, A., McClay, J., Moffitt, T. E., Mill, J., Martin, J., Craig, I. W., et al. (2002). Role of genotype in the cycle of violence in maltreated children. Science, 297, 851-854. 
Cohen, M. A. (1998). The monetary value of saving a high risk youth. Journal of Quantitative Criminology, 14, 5-33.

Cohen, M. A., \& Piquero, A. R. (2009). New evidence on the monetary value of saving a high risk youth. Journal of Quantitative Criminology, 25, 25-49.

Cohen, M. A., Piquero, A. R., \& Jennings, W. G. (2010a). Studying the costs of crime across offender trajectories. Criminology \& Public Policy, 9, 279-305.

Cohen, M. A., Piquero, A. R., \& Jennings, W. G. (2010b). Monetary costs of gender and ethnicity disaggregated group-based offending. American Journal of Criminal Justice, 35, 159-172.

Cohen, M. A., Piquero, A. R., \& Jennings, W. G. (2010c). The monetary value of early childhood interventions: Calculating the cost of bad outcomes for at-risk youth, and the benefits of interventions to reduce them. Criminal Justice Policy Review, $21,391-434$.

DeLisi, M., \& Gatling, J. M. (2003). Who pays for a life of crime? An empirical assessment of the assorted victimization costs posed by career criminals. Criminal Justice Studies, 16, 283-293.

DeLisi, M., \& Piquero, A. R. (2011). New frontiers in criminal careers research, 2000-2011: A state-of-the-art review. Journal of Criminal Justice (forthcoming).

D’Unger, A. V., Land, K. C., McCall, P. L., \& Nagin, D. S. (1998). How many latent classes of delinquent/criminal careers? Results from mixed poisson regression analysis. American Journal of Sociology, 103, 1593-1620.

Farrington, D. P. (1995). Crime and physical health: Illnesses, injuries, accidents and offending in the Cambridge Study. Criminal Behaviour and Mental Health, 5, 261-278.

Farrington, D. P. (2003). Key results from the first forty years of the Cambridge Study in delinquent development. In T. P. Thornberry \& M. D. Krohn (Eds.), Taking stock of delinquency: An overview of findings from contemporary longitudinal studies (pp. 137-183). Boston: Kluwer.

Fitzgerald, R., Mazerolle, P., Piquero, A. R., \& Ansara, D. L. (2011). Exploring sex differences among sentenced juvenile offenders in Australia. Justice Quarterly (forthcoming).

Giordano, P. C., Cernkovich, S. A., \& Rudolph, J. L. (2002). Gender, crime, and desistance: Toward a theory of cognitive transformation. American Journal of Sociology, 107, 990-1064.

Goldweber, A., Dmitrieva, J., Cauffman, E., Piquero, A. R., \& Steinberg, L. (2011). The development of criminal style in adolescence and young adulthood: Separating the lemmings from the loners. Journal of Youth and Adolescence, 40, 332-346.

Gottfredson, M. R., \& Hirschi, T. (1990). A general theory of crime. Stanford, CA: Stanford University Press.

Horney, J. D., Osgood, D. W., \& Marshall, I. H. (1995). Criminal careers in the short-term: Intra-individual variability in crime and its relation to local life circumstances. American Sociological Review, 60, 655-673.

Jennings, W., Maldonado-Molina, M. M., Piquero, A. R., Odgers, C. L., Bird, H., \& Canino, G. (2010). Sex differences in trajectories of offending among Puerto Rican youth. Crime and Delinquency, 56, 327-357.

Kazemian, L., \& Farrington, D. P. (2006). Exploring residual career length and residual number of offenses for two generations of repeat offenders. Journal of Research in Crime and Delinquency, $43,89-113$.

Kobner, O. (1893). Die Methode einer wissenschaftlichen Ruckfallsstatistik als Grundlage einer Reform der Kriminalstatistik, 13 ZEITSCHRIFT FOR DIE GESAMTE STRAFRECHTSWISSENSCHAFT 1.

Kurlychek, M. C., Brame, R., \& Bushway, S. D. (2007). Enduring risk? Old criminal records and predictions of future criminal involvement. Crime \& Delinquency, 53, 64-83.
Laub, J. H., Nagin, D. S., \& Sampson, R. J. (1998). Trajectories of change in criminal offending: Good marriages and the desistance process. American Sociological Review, 63, 225-238.

Laub, J. H., \& Sampson, R. J. (2001). Understanding desistance from crime. In M. Tonry (Ed.), Crime and justice (Vol. 28). Chicago: University of Chicago Press.

Laub, J. H., \& Sampson, R. J. (2003). Shared beginnings, divergent lives: Delinquent boys to age 70. Cambridge, MA: Harvard University Press.

Le Blanc, M., \& Loeber, R. (1998). Developmental criminology. In M. Tonry (Ed.), Crime, justice: A review of research (Vol. 23, pp. 115-198). Chicago: University of Chicago Press.

Loeber, R., Farrington, D. P., Stouthamer-Loeber, M., \& White, H. R. (2008). Violence and serious theft: Development and prediction from childhood to adulthood. New York, NY: Routledge.

Loughran, T., Paternoster, R., Piquero, A. R., \& Pogarsky, G. (2011). On ambiguity in perceptions of risk: Implications for criminal decision-making and deterrence. Criminology.

Ludwig, J., Duncan, G. J., \& Hirschfield, P. (2001). Urban poverty and juvenile crime: Evidence from a randomized housingmobility experiment. Quarterly Journal of Economics, 116, 655-679.

Lynam, D. R., Piquero, A., \& Moffitt, T. E. (2004). Specialization and the propensity to violence: Support from self-reports but not official records. Journal of Contemporary Criminal Justice, 20, 215-228.

Maldonado-Molina, M. M., Piquero, A. R., Jennings, W. G., Bird, H., \& Canino, G. (2009). Trajectories of delinquent behaviors among Puerto Rican children and adolescents at two sites. Journal of Research on Crime and Delinquency, 46, 144-181.

Maruna, S. (2001). Making good: How ex-convicts reform and rebuild their lives. Washington, D.C.: American Psychological Association.

McGee, T., \& Piquero, A. R. (2011). Crime emergence and criminal careers. In J. McGloin, C. Sullivan, \& L. W. Kennedy (Eds.), Crime emergence. NY: Routledge.

McGloin, J., \& Piquero, A. R. (2009). I wasn't alone: Collective behavior and violent delinquency. Australian and New Zealand Journal of Criminology, 42, 336-353.

McGloin, J., \& Piquero, A. R. (2010). On the relationship between cooffending network redundancy and offending versatility. Journal of Research in Crime and Delinquency, 47, 63-90.

McGloin, J. M., Sullivan, C., Piquero, A., \& Bacon, S. (2008). Investigating the stability of co-offending and co-offenders among a sample of youthful offenders. Criminology, 46, $155-188$.

Moffitt, T. E. (1993). Adolescence-limited and life-course-persistent antisocial behavior: A developmental taxonomy. Psychological Review, 100, 674-701.

Moffitt, T. E. (2006). Life-course persistent versus adolescencelimited antisocial behavior. In D. Cicchetti \& D. Cohen (Eds.), Developmental psychopathology (2nd ed.). New York: Wiley.

Monahan, K., \& Piquero, A. R. (2009). Investigating the longitudinal relation between offending frequency and offending variety. Criminal Justice and Behavior, 36, 653-673.

Mulvey, E. P., Steinberg, L., Fagan, J., Cauffman, E., Piquero, A., Chassin, L., et al. (2004). Theory and research on desistance from antisocial activity among serious juvenile offenders. Youth Violence \& Juvenile Justice, 2, 213-236.

Nagin, D. S. (2005). Group-based modeling of development. Cambridge, MA: Harvard University Press.

Nagin, D. S., Cullen, F. T., \& Jonson, C. L. (2009). Imprisonment and reoffending. In M. Tonry (Ed.), Crime and justice: A review of research (Vol. 38, pp. 115-200). Chicago: University of Chicago Press. 
Nagin, D. S., Farrington, D. P., \& Moffitt, T. E. (1995). Life-course trajectories of different types of offenders. Criminology, 33, 111-139.

Nagin, D., \& Land, K. C. (1993). Age, criminal careers, and population heterogeneity: Specification and estimation of a nonparametric, mixed poisson model. Criminology, 31, 327-362.

Nagin, D. S., \& Paternoster, R. (1991). On the relationship of past to future participation in delinquency. Criminology, 29, 163-189.

Nagin, D. S., \& Paternoster, R. (2000). Population heterogeneity and state dependence: State of the evidence and directions for future research. Journal of Quantitative Criminology, 16, 117-144.

Nagin, D. S., \& Piquero, A. R. (2010). Using the group based trajectory modeling to study crime over the life course. Journal of Criminal Justice Education, 21, 105-116.

Nagin, D. S., Piquero, A. R., Scott, E., \& Steinberg, L. (2006). Public preferences for rehabilitation versus incarceration of juvenile offenders: Evidence from a contingent valuation survey. Criminology \& Public Policy, 5, 627-652.

Nieuwbeerta, P., \& Piquero, A. R. (2008). Mortality rates and causes of death of convicted Dutch criminals 25 years later. Journal of Research in Crime and Delinquency, 45, 256-286.

Odgers, C. L., Caspi, A., Broadbent, J. M., Dickson, N., Hancox, R. J., Harrington, H. L., et al. (2007). Conduct problem subtypes in males predict differential adult health burden. Archive of General Psychiatry, 64, 476-484.

Olds, D., Henderson, C. R., Cole, R., et al. (1998). Long-term effects of nurse home visitation on children's criminal and antisocial behavior: 15-year follow-up of a randomized controlled trial. Journal of the American Medical Association, 280, 1238-1244.

Osgood, D. W. (2005). Making sense of crime and the life course. The Annals of the American Academy of Political and Social Science, 602, 196-211.

Paternoster, R., Dean, C. W., Piquero, A., Mazerolle, P., \& Brame, R. (1997). Generality, continuity, and change in offending. Journal of Quantitative Criminology, 13, 231-266.

Petras, H., Nieuwbeerta, P., \& Piquero, A. R. (2010). Participation and frequency during criminal careers over the life span. Criminology, 48, 607-637.

Piquero, A. R. (2008). Taking stock of developmental trajectories of criminal activity over the life course. In A. Liberman (Ed.), The long view of crime: A synthesis of longitudinal research (pp. 23-78). New York: Springer.

Piquero, A. R., \& Blumstein, A. (2007). Does incapacitation reduce crime? Journal of Quantitative Criminology, 23, 267-286.

Piquero, A. R., Blumstein, A., Brame, R., Haapanen, R., Mulvey, E. P., \& Nagin, D. S. (2001). Assessing the impact of exposure time and incapacitation on longitudinal trajectories of criminal offending. Journal of Adolescent Research, 16, 54-74.

Piquero, A. R., Brame, R., \& Lynam, D. (2004). Studying the factors related to career length. Crime and Delinquency, 50, 412-435.

Piquero, A. R., Brame, R., Mazerolle, P., \& Haapanen, R. (2002a). Crime in emerging adulthood. Criminology, 40, 137-170.

Piquero, A. R., Cullen, F. T., Uneever, J. D., Piquero, N. L., \& Gordon, J. A. (2010a). Never too late: Public optimism about juvenile rehabilitation. Punishment \& Society, 12, 187-207.

Piquero, A. R., Farrington, D. P., \& Blumstein, A. (2003). The criminal career paradigm. In M. Tonry (Ed.), Crime and justice: A review of research (Vol. 30). Chicago: University of Chicago Press.

Piquero, A. R., Farrington, D. P., \& Blumstein, A. (2007). Key issues in criminal careers research: New analyses from the Cambridge study in delinquent development. New York: Cambridge University Press.

Piquero, A. R., Farrington, D. P., Nagin, D. S., \& Moffitt, T. E. (2010b). Trajectories of offending and their relation to life failure in late middle age: Findings from the Cambridge Study in
Delinquent Development. Journal of Research in Crime \& Delinquency, 47, 151-173.

Piquero, A. R., Farrington, D. P., Welsh, B. C., Tremblay, R., \& Jennings, W. (2009). Effects of early family/parent training programs on antisocial behavior and delinquency. Journal of Experimental Criminology, 5, 83-120.

Piquero, A. R., Hawkins, J. D., \& Kazemian, L. (2011a). Criminal career patterns between adolescence and emerging adulthood. In R. Loeber \& D. P. Farrington (Eds.), Transitions from juvenile delinquency to adult crime: Criminal careers, justice policy and prevention. New York: Oxford university press.

Piquero, A. R., Jennings, J., \& Farrington, D. P. (2010c). On the malleability of self-control: Theoretical and policy implications regarding a general theory of crime. Justice Quarterly, 27, 803-834.

Piquero, A. R., Jennings, W., \& Farrington, D. P. (unpublished manuscript). The monetary costs of crime to middle adulthood: Findings from the Cambridge Study in Delinquent Development.

Piquero, A. R., MacDonald, J., \& Parker, K. F. (2002b). Race, local life circumstances, and crime. Social Science Quarterly, 83, 654-670.

Piquero, A. R., \& Moffitt, T. E. (2005). Explaining the facts of crime: How the developmental taxonomy replies to Farrington's invitation. In D. P. Farrington (Ed.), Integrated developmental \& life-course theories of offending: Advances in criminological theory (pp. 51-72). New Brunswick, NJ: Transaction.

Piquero, A. R., Shepherd, I., Shepherd, J., \& Farrington, D. P. (2011b). Impact of offender trajectories on health: Disability, hospitalization, and death by middle age in the Cambridge Study in Delinquent Development. Criminal Behaviour and Mental Health. doi:10.1002/cbm. 810 .

Piquero, A. R., Sullivan, C., \& Farrington, D. P. (2011c). Assessing differences among offenders who offend a lot over a short time period compared to offenders who offend a little over a long time period. Criminal Justice \& Behavior, 37, 1309-1329.

Quetelet, A. (1831). Research on the propensity for crime at different ages. Cincinnati, OH: Anderson Publishing Co (Translated with an introduction by Sawyer F. Sylvester (1984)).

Robins, L. N. (1978). Sturdy childhood predictors of adult antisocial behavior: Replications from longitudinal studies. Psychological Medicine, 8, 611-622.

Sampson, R. J., \& Laub, J. H. (1993). Crime in the making: Pathways and turning points through life. Cambridge, MA: Harvard University Press.

Sampson, R. J., \& Laub, J. H. (1997). A life-course theory of cumulative disadvantage and the stability of delinquency. In T. P. Thornberry (Ed.), Developmental theories of crime and delinquency, advances in criminological theory (pp. 133-161; Vol. 7). New Brunswick, NJ: Transaction.

Shaw, C. R. (1930). The Jack-Roller: A delinquent boy's own story. Chicago: University of Chicago Press.

Shover, N. (1996). Great pretenders: Pursuits and careers of persistent thieves. Boulder, CO: Westview Press.

Sullivan, C., \& Piquero, A. R. (2010). Investigating stability and change in substance use and criminal activity using a synthesized longitudinal modeling approach. Journal of Drug Issues, 41, 63-92.

Sullivan, C., \& Piquero, A. R. (2011). Criminal career research: A statistical and substantive comparison of growth modeling approaches. In J. MacDonald (Ed.), Measuring crime and criminality, advances in criminological theory (Vol. 17). New Brunswick, NJ: Transaction Publishing.

Thornberry, T. P., \& Krohn, M. D. (2003). Comparison of self-report and official data for measuring crime. In J. Pepper \& C. Petrie (Eds.), Measurement problems in criminal justice research: Workshop summary. Washington, DC: National Academies Press. 
van Mastrigt, S. B., \& Farrington, D. P. (2009). Co-offending, age, gender, and crime type: Implications for criminal justice policy. British Journal of Criminology, 49, 552-573.

Welsh, B. C., Loeber, R., Stevens, B. R., Stouthamer-Loeber, M., Cohen, M. A., \& Farrington, D. P. (2008). The costs of juvenile crime in urban areas: A longitudinal perspective. Youth Violence and Juvenile Justice, 6, 3-27.

Wolfgang, M. E., Figlio, R. M., \& Sellin, T. (1972). Delinquency in a birth cohort. Chicago: University of Chicago Press.

Wright, R. T., \& Decker, S. H. (1994). Burglars on the job: Streetlife and residential break-ins. Boston: Northeastern University Press.

Wright, R. T., \& Decker, S. H. (1997). Armed robbers in action: Stickups and street culture. Boston: Northeastern University Press.

\section{Author Biography}

Alex R. Piquero is Professor in the Program in Criminology in the School of Economic, Political, and Policy Sciences at the University of Texas at Dallas, Adjunct Professor Key Centre for Ethics, Law, Justice, and Governance, Griffith University and Co-Editor of the Journal of Quantitative Criminology. His research interests include criminal careers, criminological theory, and quantitative research methods. He has received several research, teaching, and mentoring awards, and has been elected Fellow of both the American Society of Criminology and the Academy of Criminal Justice Sciences. 